\title{
Using an Intervention Mapping Approach to Develop a Program for Preventing High Blood Pressure in a Marginalized Afro-Colombian Population: A Community- Based Participatory Research
}

\section{Deivis Nicolas Guzman-Tordecilla' ${ }^{1}$ - Diego Lucumi ${ }^{1}$ - Maricel Peña ${ }^{2}$}

Accepted: 11 January 2022 / Published online: 29 January 2022

(c) The Author(s), under exclusive licence to Springer Science+Business Media, LLC, part of Springer Nature 2022

\begin{abstract}
The prevention of high blood pressure (HBP) is an important public health initiative worldwide, since HBP is the main risk factor for cardiovascular diseases and increases the damage caused by coronavirus disease 2019 (COVID-19). We designed, implemented, and evaluated a program to identify effective and sustainable interventions for preventing HBP in a marginalized black population. Our study was conducted in Quibdó, a city in Colombia with the highest poverty rate and located in the Pacific coast, a subregion in Colombia with the highest prevalence of HBP. We followed an intervention mapping framework using a community-based participatory research approach. Focus groups, photovoice, literature reviews, and cross-sectional quantitative surveys were used for data collection. The community chose the time, place, and type of physical activity; led the physical activities; and strengthened their skills in seeking resources in their community to sustain the program. The evaluation was aimed at determining whether the interventions were able to achieve the program's primary aim. We used a before (September 2016) and after (December 2017) design for the evaluation. To decrease the selection bias and allow comparisons between homogeneous groups, we used a propensity score matching technique. The steps required to create a self-sustaining physical activity program were provided in detail. The pre-post test showed a decrease of the HBP (systolic, $13.4 \%$ points; $p=0.018$; diastolic, $6.5 \%$ points; $p=0.002$ ). The program may be an effective and self-sustaining intervention, and it can be replicated by policymakers and implemented in other population groups.
\end{abstract}

Keywords Intervention mapping · Physical activity · Prevention · Hypertension · Vulnerable communities · Colombia 


\section{Introduction}

Prevention of high blood pressure (HBP) has become an important public health initiative worldwide (Diaz \& Shimbo, 2013) because hypertension is the primary risk factor for cardiovascular diseases (CVDs) and increases the damage caused by coronavirus disease 2019 (COVID-19) (Nikoloski et al., 2021). People with noncommunicable diseases (NCDs), such as cardiovascular diseases, are at a higher risk of death from COVID-19 (Nikoloski et al., 2021). Furthermore, HBP frequently occurs in populations with higher rates of unsatisfactory basic needs or in people with lower socioeconomic status (Leng et al., 2015).

Majority of countries in Latin America have medium and low incomes. This could explain why the region reports an HBP prevalence of $39 \%$, which is higher than that of other countries worldwide; however, women have the highest rate of HBP in this region (men: 36.3\% vs. women: 39.6\%) (Kandala \& Uthman, 2015).

In Colombia, the prevalence of HBPs is $25 \%$. In the Colombian Pacific Coast, where is located Quibdó, the city where this study was conducted, the prevalence of HBP is $38.3 \%$ (Lucumi, 2014). Quibdó is believed to have a prevalence of HBP similar to the Colombian Pacific Coast, is the third most populated city in this region and shares with it its sociocultural and demographic conditions. Furthermore, CVD is the leading cause of death in Quibdó (Secretaría de Salud del Chocó, 2015), and it is known that CVD is one of the outcomes of HBP (Lim et al., 2012).

Evidence has shown a consistent and temporal relationship between physical activity (PA) and HBP (Diaz \& Shimbo, 2013), which limits the damage caused by COVID-19. Despite this evidence, $46.5 \%$ of individuals aged 17 years living in Colombia have a sedentary lifestyle, the majority of whom are women (Ministerio de Salud y Protección Social, 2018). For Quibdó, the prevalence of PA is unknown, but the obesity rates have increased (obesity rate for Chocó: 20.30 and Colombia: 15.50), and these results are partly associated with PA (Secretaría de Salud del Chocó, 2015).

Some authors have shown an association between low PA levels and difficulties in the replication, support, and evaluation of interventions (Mendoza-Vasconez et al., 2016). This is because the design of these interventions have not been evaluated, are not context sensitive, and do not have adequate theoretical, methodological, and practical foundations (Glanz et al., 2008; Gómez et al., 2002). These practices generate interventions that are not sustainable over time, either because of attrition of the participants or because the resources have been exhausted (Abu-Omar et al., 2017; Lawlor et al., 2003).

In addition, people with more unsatisfactory basic needs report lower PA levels. This includes groups in which PA interventions are more difficult to implement (World Health Organization, Office for Europe, 2013). Therefore, practitioners must identify strategies to facilitate population groups with these characteristics design and replicate effective interventions according to their living conditions and resources (Glanz et al., 2008; Lawlor et al., 2003).

Among the multiple actions developed to address the problem described above, community interventions seem to be a good option because they allow participatory processes and recognition of the context (Heath et al., 2012). Nevertheless, for these 
interventions to be effective, they must be rigorously designed, incorporating practical and theoretical elements (Glanz et al., 2008).

However, interventions in PA aimed at the prevention of HBP that meet these characteristics are scarce in Colombia and Latin America (Garba \& Gadanya, 2017; Gómez et al., 2002). In order to respond to this need, this study aimed to design, implement, and evaluate a program for PA promotion and prevention of HBP in marginalized Colombian city.

\section{Methods}

Our study described the design of a PA community program conducted in Quibdó between 2014 and 2017. It incorporated a participatory approach and involved the rigorous application of intervention mapping (IM), which guides the design, implementation, and evaluation of interventions in health education (Bartholomew et al., 1998). This study was approved by the institutional review board of the Universidad de los Andes, Colombia.

\section{Area of study}

In Quibdo, $89.5 \%$ of the population live in poverty, the unemployment rate is $15 \%$, and $90 \%$ of the population are Afro-Colombians, with a lower percentage of indigenous and mestizo populations. Black and indigenous populations are the main ethnic and racial minorities and have experienced historical marginalization in Colombia (National Administrative Department of Statistics-DANE \& Banco de la República De Colombia, 2016; Lucumi, 2014).

The presented study was conducted in the neighborhood of Reposo Dos in Quibdó, located in the northern part of the city. This zone has poor road conditions, greater settlement of displaced populations, limited presence of government institutions, and a higher proportion of households with unmet basic needs compared with other areas of the city.

\section{Participants}

The program was developed by the members of the community and academia. All participants were actively involved in all stages of the program. From the community participated Te Abrazo Choco Foundation, Reposo Dos neighborhood school, and community action board of the neighborhood Reposo Dos. From the academia, an expert in community interventions and HBP, a master of public health student, two nurses, and an apsychology student and three nursing students participated.

\section{Intervention Strategy}

Our study was performed based on the IM framework, which recognizes that programs can have an impact on behavioral and/or environmental factors since the determinants of health are personal and environmental factors. IM framework also 
proposes five steps for the design of public health interventions: (1) proximal program objectives, (2) theoretical methods and practical strategies, (3) design program, (4) adoption and implementation, and (5) monitoring and evaluation (Bartholomew et al., 1998). In this study, step 4 was not described.

\section{Needs and Resources Assessment}

As IM requires a previous stage called needs assessment (Bartholomew et al., 1998), we conducted a formative research and literature review.

\section{Formative Research}

Between 2014 and 2015, we conducted a qualitative study with 30 participants aged 18-60 years (16 women and 14 men) from the three neighborhoods in Quibdo (La Yesquita, Uribe Vélez, and Reposo Dos). Qualitative data were collected using focus groups and photovoice. Then, content analysis was performed using the NVivo ${ }^{\circledR} 10$ software for the organization, encoding, and reading of the data.

\section{Literature Review}

We conducted a literature review to identify the theoretical determinants associated with PA and the different effective interventions to increase the PA levels in contexts similar to our study area. The search focused on finding studies conducted in adults and was performed in PubMed, Web of Science, APA Psynet, Lilacs, and Scielo from January 2000 to February 2016. The English search terms used were community intervention, physical activity, motor activity, low income, poor, and marginalization, while the Spanish search terms used were intervención comunitaria, actividad fisica, participación comunitaria, actividad motora, pobreza, bajos ingresos, and marginal$i d a d$. All search terms were selected based on the Medical Subject Headings (MeSH) and its Spanish counterpart Health Sciences Descriptors (DeCS).

\section{Step 1. Proximal Program Objectives}

In this step, we specified the general aims of the program. The specific aims were set to achieve the general aims. Subsequently, for each specific aim, we identified possible barriers that could affect the achievement of the main aim. The barriers provided information about problems that people faced when trying to reach the aims of the program.

From the previously identified barriers, we mapped the theoretical determinants for behavioral change. The determinants of behavior are crucial, as they can be used to identify the factors that need to be changed in order to achieve the program's general aim (Taylor et al., 2013).

The information needed for this step was obtained during the needs assessment. The results of the literature review, focus groups, and photovoice were discussed by 
the members of the community and academia in order to determine the objectives and barriers and select the determinants of behavior in this particular community.

\section{Step 2. Selection of Intervention Methods Based on Theory and Practical Strategies}

In this step, we selected theoretical methods that could influence changes in the theoretical determinants of participants' behavior were selected. For the selection of techniques for behavioral change, the taxonomy developed by Abraham and Michie and the expert consensus developed by Michie et al. were reviewed, and the theoretical approaches identified in the literature review were taken into account (Abraham \& Michie, 2008; Michie et al., 2008).

The theoretical information was used as a basis for developing practical strategies. The findings of the focus groups and photovoice and the information obtained from the review of articles were the primary elements discussed by the members of the community and academia in order to decide which strategies were more feasible, considering the context in which the program would be implemented. Moreover, all strategies were classified into several components, such as educational, community organization, or environmental, to identify the possible fields from which the interventions could be selected in order to achieve the program's aim.

\section{Step 3. Design and Organization of the Program}

After, we identify the barriers to PA in this community and the theoretical determinants for each of the barriers along with their respective techniques for behavioral change, the members of the community and academia worked on designing the intervention at the intrapersonal, interpersonal, and community levels. In this step, (1) the program's scope and limitations were determined, (2) the content of the proposed intervention was assessed to ensure its applicability in the population of interest, (3) the appropriate methods for engaging with the participants were selected, (4) the conditions or internal rules for the program's operation were mapped, (5) the community resources required to implement the intervention were assessed, and (6) the degree of participation of the community members was determined.

The program's design was based on the evidence gathered during the needs assessment and from the community's experience and knowledge of its context and behavior. Three workshops were held, and the community of Reposo Dos was invited to discuss the program's design. The observations obtained from these workshops were incorporated in the final design of the program.

\section{Step 5. Program Evaluation}

In the last step, we conducted an evaluation to determine whether the interventions reached the program's aim a year after its implementation. A pre-post design was 
used to conduct the evaluation. The pre-intervention group consisted of a sample of measurements collected in September 2016 at the opening of the program. A total of 154 observations were collected from all participants who attended the first session, and post-intervention samples were collected from those who participated in the program for at least six months and attended at least one 45-minute session per week between November 2016 and December $2017(n=60)$. The samples for both the pre-and post-intervention groups were obtained from residents of Reposo Dos.

\section{Outcome Variables}

The variables of interest in this study were systolic and diastolic blood pressure, both measured as continuous outcomes. The blood pressure was measured by well-trained nursing students using mercury sphygmometers and stethoscopes. The participants were asked to sit down and follow the recommendations described in the Seventh Report of the Joint National Committee (National High Blood Pressure Education Program, 2004).

In addition, covariates such as age, body mass index and abdominal circumference were measured quantitatively. Other variables, such as sex, socioeconomic level (low, middle, and high income) (Estrato socioeconomico: based on their houses' physical state and the surroundings used by the national government) (National Administrative Department of Statistics-DANE, 2015), race (Afro-Colombian, indigenous, and mestizo), and educational level (university graduate and university under-graduate), were considered nominal variables. These data were collected by the nursing students.

\section{Analytical Plan}

First, we obtained descriptive statistics for the outcome variables and covariates in both groups. Then, the data from the pre- and post-treatment groups were obtained to create two propensity score matching (PSM) models that were used to evaluate the program's effect on the reduction of blood pressure. PSM decreases selection bias and allows comparisons between homogeneous groups (common characteristics) by randomly selecting the participants with identical characteristics in both groups (preand post-intervention groups) (Kane et al., 2020). All results were evaluated using a probit regression model with robust errors. The matching variables and covariates in the analyses were age, sex, body mass index and abdominal circumference. All study participants had low income, identified themselves as Afro-Colombians, and were university under-graduates; hence, these variables were not included in the analyses (absence of variability). The matching quality was assessed based on previous recommendation (Guzman-Tordecilla et al., 2021).

was obtained from all participants. Those who participated in the focus groups and the photovoice provided a written consent, while the rest of the participants provided a verbal consent. All statistical analyses were performed using Stata ${ }^{\circledR}$ version 14. 


\section{Results}

\section{Needs Assessment}

Formative Research We found that the main barriers to PA were related to environmental and social factors. Lack of sports and recreational facilities, long travel distances, and long working hours were identified as barriers to PA. Insecurity in the neighborhood and the lack of people trained in PA in the community were also cited as barriers.

Literature Review Thirty-four relevant studies were found and 10 met the search terms (Balcázar et al., 2012; Blackford et al., 2015; Coleman et al., 2012; Denman et al., 2014; Izumi et al., 2015; Keyserling et al., 2008; Koniak-Griffin et al., 2015; Lynch et al., 2014; Pazoki et al., 2007; Schulz et al., 2015). Based on the articles included in our study, transtheoretical and social-ecological models and social cognitive theory were identified as the most commonly used theories to guide interventions implemented in similar settings.

Theoretical Approaches The basic premise of the transtheoretical model is that behavioral change is a process and not an act, and individuals have different levels of motivation or willingness to change (Prochaska \& Velicer, 1997). In contrast, the social cognitive theory suggests that human behavior is explained in three ways: personal factors, environmental influences, and an interaction between personal and environmental factors (Stacey et al., 2015). This aligns with the social-ecological model, which indicates that the behaviors are influenced by the factors at different levels (Mcleroy et al., 1988). A basic premise of this theory is that people learn not only through their own experiences, but also by observing the actions of others (especially close people) and the results of those actions.

We observed differences in the PA community interventions reported in the articles included in the literature review. From our review, we found that the most popular interventions were aerobic exercises, followed by walking, information about PA, and health information.

\section{Step 1. Proximal Program Objectives}

The main objective of the program was to reduce blood pressure in people aged $>17$ years who participated in the PA program. In order to achieve this, six specific aims were included, along with their barriers and determinants (Table 1). 
Table 1 Specific objectives, barriers and determinants for the PA program.a

\begin{tabular}{|c|c|c|}
\hline Specific objectives & Barriers & Determinants \\
\hline $\begin{array}{l}\text { To identify resources and op- } \\
\text { portunities for PA }\end{array}$ & $\begin{array}{l}\text { Lack of organization in the community to } \\
\text { put strategies in place to identify resources } \\
\text { and opportunities to do PA }\end{array}$ & $\begin{array}{l}\text { - Empowerment } \\
\text { - Information/knowledge }\end{array}$ \\
\hline $\begin{array}{l}\text { To create collective agree- } \\
\text { ments to facilitate PA }\end{array}$ & $\begin{array}{l}\text { Lack of collective agreements to facilitate } \\
\text { PA }\end{array}$ & $\begin{array}{l}\text { - Social norms } \\
\text { - Critical thinking }\end{array}$ \\
\hline $\begin{array}{l}\text { To work on logistics in the } \\
\text { neighborhood to incentivize } \\
\text { PA }\end{array}$ & $\begin{array}{l}\text { Lack of knowledge about the needed logis- } \\
\text { tics to implement a PA program }\end{array}$ & $\begin{array}{l}\text { - Information/knowledge } \\
\text { - Empowerment } \\
\text { - Environment }\end{array}$ \\
\hline $\begin{array}{l}\text { To involve natural social } \\
\text { support networks to advertise } \\
\text { and do PA }\end{array}$ & $\begin{array}{l}\text { Lack of knowledge about strategies that } \\
\text { would allow social support to incentivize } \\
\text { PA }\end{array}$ & - Social Support \\
\hline $\begin{array}{l}\text { To develop and strengthen } \\
\text { motor, emotional, cognitive } \\
\text { and social skills to do PA }\end{array}$ & $\begin{array}{l}\text { Lack of knowledge and/or lack of abilities } \\
\text { to do PA }\end{array}$ & $\begin{array}{l}\text { - Information/knowledge } \\
\text { - Behavior's capac- } \\
\text { ity (knowledge of the } \\
\text { behavior and ability for } \\
\text { its execution) }\end{array}$ \\
\hline $\begin{array}{l}\text { To modify beliefs that limit the } \\
\text { execution of PA }\end{array}$ & $\begin{array}{l}\text { Wrong beliefs such as PA can only be } \\
\text { executed in specific places in the city; } \\
\text { they also seemed to believe that they } \\
\text { could not lead a PA program as that was a } \\
\text { Government duty or that they didn't have } \\
\text { enough resources to lead and execute such } \\
\text { programs, among others }\end{array}$ & $\begin{array}{l}\text { - Information/knowledge } \\
\text { - Self- efficiency } \\
\text { Popular beliefs } \\
\text { - Motivation to achieve } \\
\text { (To determine subjective } \\
\text { norm) }\end{array}$ \\
\hline
\end{tabular}

an this matrix we show the specific objective for the program, the barriers to achieve said objectives and the behavior's determinants linked to the barriers

\section{Step 2. Selection of Intervention Methods Based on the Theory and Practical Strategies}

Table 2 Behavior change techniques used in the theoretical-mapped determinants for the PA programa

- Increase skills: problem solving, decision making and goal setting

- Practice of relevant skills

- Homework

- Perform the behavior in several sections

- Self-monitoring

- Varied tasks, starting with easy tasks

- Copy of skills

- Feedback

- Rewards (encourage self-evaluation)

- Persuasive communication

- Customized message

- Rewards, incentives (encourage self-evaluation)

- Organizational development

- Create specific goals or targets
- Information with respect

- Planning and implementation

- Decision making

- Contract

- Social process of stimulation, pressure and support

- Modeling

- Organizational development

- Environmental change (to define objectives that facilitate behavior)

- Social process of motivation, pressure and support

- Monitoring

- Self-monitoring

- Information regarding behaviour and results

a List of behavior change techniques selected from the taxonomy of Abraham and Michie in 2008 and Michie et al. in 2008 for the theoretical determinants of behavior mapped to the program 
The second step involved the identification of theoretical methods that have been suggested to be effective in changing the theoretical determinants. We carried out this based on the previously described techniques of behavioral change, the transtheoretical model, and social cognitive theory. From this exercise, we identified theoretical methods for changing the determinants of behavior. The behavior-change techniques used in this study are listed in Table 2.

\section{Step 3. Design and Organization of the Program}

Initially, this step included an expectation campaign. A contest was held. During the contest, the residents of the Reposo Dos neighborhood were instructed to design a logo and create a name for the PA program. During the open day, the adults participated in aerobic exercises, while the children participated in recreational activities. All participants were provided with fruits and water, and their blood pressure and anthropometric measurements were obtained. At the end of the event, the winner's name and logo were announced (Fig. 1). The award was given by both, the community members, and external guests.

\section{Design of Program}

The members of the community chose to perform an aerobic dance during the program as this was the preferred activity of the population. Five members of the community were selected to receive first aid and aerobic dance training. In this way, all the information obtained during the training can be replicated, leading the PA workout program.

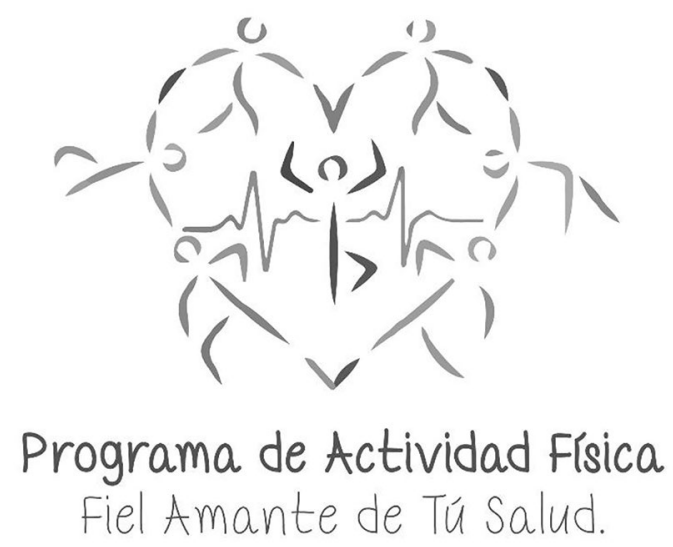

Fig. 1 Logo of the physical activity program. (Note: A contest was held among community members to select a logo and name for the program. The winning logo and name were selected by external guests and the community's popular vote in September 2016) 
Scope and Limitations of the Program As previously mentioned, the program was conducted in the Reposo Dos neighborhood. People of all ages and from any part of the city were invited to participate in the program. Moreover, the possibility of car-

Table 3 Example of change matrix of PA program for Prevention of high Blood Pressure

\begin{tabular}{|c|c|c|c|c|c|c|}
\hline $\begin{array}{l}\text { Specific } \\
\text { objectives }\end{array}$ & Barriers & Determinants & $\begin{array}{l}\text { Intervention } \\
\text { levels }\end{array}$ & Techniques & Strategies & $\begin{array}{l}\text { Com- } \\
\text { ponents }\end{array}$ \\
\hline \multirow[t]{3}{*}{$\begin{array}{l}\text { To } \\
\text { recognize } \\
\text { resources } \\
\text { and op- } \\
\text { portunities } \\
\text { for the PA } \\
\text { workout to } \\
\text { take place }\end{array}$} & $\begin{array}{l}\text { Lack of } \\
\text { commu- } \\
\text { nity orga- } \\
\text { nization or } \\
\text { strategies } \\
\text { focused on } \\
\text { identifica- } \\
\text { tion of } \\
\text { resources } \\
\text { and op- } \\
\text { portunities } \\
\text { to carry out } \\
\text { PA }\end{array}$ & Empowerment & Community & $\begin{array}{l}\text { Organi- } \\
\text { zational } \\
\text { develop- } \\
\text { ment } \\
\text { To design } \\
\text { specific } \\
\text { aims }\end{array}$ & $\begin{array}{l}\text { Conforma- } \\
\text { tion of a } \\
\text { coalition, } \\
\text { where to } \\
\text { create a } \\
\text { team that } \\
\text { would } \\
\text { be held } \\
\text { responsible } \\
\text { for the } \\
\text { function- } \\
\text { ing and } \\
\text { sustainabil- } \\
\text { ity of the } \\
\text { program } \\
\text { (adminis- } \\
\text { trative and } \\
\text { community } \\
\text { promoters) }\end{array}$ & $\begin{array}{l}\text { Com- } \\
\text { munity } \\
\text { organi- } \\
\text { zation }\end{array}$ \\
\hline & & $\begin{array}{l}\text { Knowledge/ } \\
\text { Information }\end{array}$ & Intrapersonal & $\begin{array}{l}\text { Informa- } \\
\text { tion with } \\
\text { respect }\end{array}$ & $\begin{array}{l}\text { Discussion } \\
\text { of potential } \\
\text { resources } \\
\text { for the de- } \\
\text { velopment } \\
\text { of the PA } \\
\text { program } \\
\text { with the } \\
\text { community }\end{array}$ & $\begin{array}{l}\text { Educa- } \\
\text { tional }\end{array}$ \\
\hline & & Empowerment & Community & $\begin{array}{l}\text { Planning } \\
\text { and imple- } \\
\text { mentation } \\
\text { Decision } \\
\text { making } \\
\text { Contract }\end{array}$ & $\begin{array}{l}\text { Identifica- } \\
\text { tion of spe- } \\
\text { cific places } \\
\text { where the } \\
\text { workout } \\
\text { could take } \\
\text { place } \\
\text { Creation of } \\
\text { communal } \\
\text { savings } \\
\text { where } \\
\text { those who } \\
\text { attended } \\
\text { the work- } \\
\text { out would } \\
\text { contribute } \\
\text { with a } \\
\text { voluntary } \\
\text { sum. }\end{array}$ & $\begin{array}{l}\text { Com- } \\
\text { munity } \\
\text { organi- } \\
\text { zation } \\
\text { Envi- } \\
\text { ron- } \\
\text { mental }\end{array}$ \\
\hline
\end{tabular}


rying out activities outside the neighborhood, such as marathons or walks, were also considered.

Intervention Content To ensure that the intervention was relevant to the population, members of the community selected the songs that would be played during the aerobic dance. They also prepared short messages related to healthy eating and PA that were reproduced before and after the PA days. The content of the messages was reviewed by members of the academia, and the voice used to record the messages was selected by the members of the community.

Mechanisms for Attracting Participants The expectation campaign was a useful strategy because was used to announce the program's launch date. We also employed Locally popular communication strategies such as criers, distribution of flyers, and word of mouth.

Conditions or Internal Rules for the Operation of the Program We initially selected a group of people as promoters who were responsible for carrying out the PA days. The other group was assigned for the promotion and administrative tasks of the program. These groups held monthly meetings to discuss the achievements and difficulties experienced during the program implementation. In addition, the community members agreed to perform PA workouts for 45 min once a week and then increase to three times a week at 5 or $6 \mathrm{pm}$, which was the time when people finished work or housework and was a safe time for them to be out in the neighborhood.

Community Resources that Facilitated the Intervention A speaker was acquired for the program. The use of speakers allowed other people in the different parts of the neighborhood to perform the workout, which was initially performed in the school.

Community Members' Participation The members developed a sense of ownership of the program since they were considered leaders. This allowed members of the community to take responsibility in directing $100 \%$ of the program.

An example of the integration of the process carried out based on the program's specific objectives, design, and organization is presented in Table 3.

\section{Step 5. Program Evaluation}

From the initial sample of 254 participants (pre-intervention $=60$ and post-intervention group =24), 60 participants from both groups had common characteristics and were included in this study. Of the total sample, 28 observations were obtained from the post-intervention group and 32 were obtained from the pre-intervention group. Approximately $87 \%$ of the participants were women, and the average age for both groups was 28 years ( $\mathrm{SD}=10.48$; rank: 18-60); the total participants had an average body mass index of $28.8(\mathrm{SD}=5.78)$, a systolic pressure of $112 \mathrm{mmHg}$ (SD $=14.75)$, a diastolic pressure of $75 \mathrm{mmHg}(\mathrm{SD}=9.07)$, and abdominal circumference 
of $86.30 \mathrm{~cm}$. All participants were Afro-Colombian, had low resources, and were university under-graduates.

With regard to the PSM models, a sensitivity analysis was carried out as the analysis results of a small sample of participants may vary according to the pairing technique. Based on the above findings, the models were run with the closest neighbors (1:1) and the kernel. Both methods showed similar results. Systolic blood pressure decreased by $-13.4 \%$ points with a $p$-value of 0.018 , while diastolic blood pressure decreased by $-6.5 \%$ points with a $p$-value of 0.002 .

\section{Discussion}

We presented a detailed summary of how the IM technique was used to develop a multifaceted PA program with a participatory approach based on theoretical, methodological, and practical evidence to reduce blood pressure levels in adults. To the best of our knowledge, this was one of the first studies conducted in Latin America using the IM framework with a participatory approach to prevent HBP among adults living in a marginalized urban area.

The program reported in this study was unlike other programs implemented in Colombia (Gaffney et al., 2019). As rigorous exercise with recognition of the context was carried out, the resources for and barriers to the implementation of the program were identified. The community participated in the design of the program, which allowed the appropriation and generation of capacity in the community and resulted in the operation of a program using only their resources, thus facilitating the sustainability of the intervention until 1 year after its implementation.

In addition, the design of this study facilitated replication in other places and populations. We described how the theoretical, empirical, and practical components used to change behavior in the program were incorporated in a structured manner. The potential to replicate interventions and design programs for different topics and populations using the IM technique has been previously demonstrated (Bartholomew et al., 1998; Taylor et al., 2013).

The program pre-post test evaluation suggests that an intervention using the characteristics presented in this study resulted in a decrease in blood pressure levels. Similarly, a systematic review showed that the design of interventions for the prevention of diseases based on the IM framework can have the desired effect between $9 \%$ and $28 \%$, which is partly due to the use of theoretical determinants that are crucial to ensure a successful implementation of the program (Garba \& Gadanya, 2017).

Table 4 Change on the blood pressure, pre-post evaluation results

\begin{tabular}{lllll}
\hline Variable & Coefficient & Standard error & $p$-value & CI 95\% \\
\hline Systolic blood pressure & -0.134 & 5.66 & 0.018 & $-0.2451-0.0232$ \\
Diastolic blood pressure & -0.065 & 2.10 & 0.002 & $-0.1068-0.0244$ \\
\hline
\end{tabular}

Note: The covariates of the PSM models were age, sex, body mass index and abdominal circumference. CI: Confidence interval 


\section{Limitations}

One of the main limitations of IM, which has been previously reported, is that it requires a large amount of time for its development (Taylor et al., 2013). This may be true given that this study was conducted between 2014 and 2017 . However, this period allowed the development of a context-sensitive intervention, encouraged the participation of community members, facilitated their cultural adaptation, and decreased the blood pressure levels. Another limitation is that the evaluation did not include a control group and had a relatively small sample size. Nevertheless, a PSM model was developed, which decreased the selection and comparison bias between the samples, although it should be clarified that the use of PSM model does not imply causality. Additionally, the outcome was statistically significant, making this a potentially cost-effective option for policymakers from low- and middle-income countries because the program enabled the reduction of BP levels and used the resources already available in the community for its development. Future studies could explore this design using a larger sample size, and it could be evaluated in other populations using a control group.

Another limitation of this study was that it used the 1998 version of the MI approach reported by Bartholomew et al. (Bartholomew, Parcel, \& Kok, 1998) and the 2008 version of behavior change techniques reported by Abraham and Michie (Abraham \& Michie, 2008). More recent versions of these studies have been published. Readers are encouraged to consult more recent versions of these studies.

Acknowledgements We gratefully acknowledge Te Abrazo Choco Fundation, Claudia Perea, Juanita Tocasuckyl, Silvia Quiroz, Jorge Gil, Centro de Acondicionamiento Físico Body Evolution, Isaac Rodriguez Martinez School, and Yodhy Parra-Castro for your support in the development of the program. This study was funded by the Gobernación del Departmento del Chocó, Universidad Tecnologica del Chocó, and the Programa de Investigación en Comportamientos y Educación en Salud (PICES)-Facultad de Ciencias Sociales, Alberto Lleras Camargo School of Government and Vicerrectoría de Investigaciones of the Universidad de los Andes. The contents are the responsibility of the authors and do not necessarily reflect the views of the organizations.

Responsibility for the Work All authors participated in the design, implementing, and evaluating of the program, in the writing and approved the manuscript before submission.

\section{Declarations}

Conflict of Interest The authors declare that they have no conflict of interest.

\section{References}

Abraham, C., \& Michie, S. (2008). A taxonomy of behavior change techniques used in interventions. Health Psychology, 27(3), 379-387. https://doi.org/10.1037/0278-6133.27.3.379

Abu-Omar, K., Rütten, A., Burlacu, I., Schätzlein, V., Messing, S., \& Suhrcke, M. (2017). The costeffectiveness of physical activity interventions: A systematic review of reviews. Preventive Medicine Reports, 8(April), 72-78. https://doi.org/10.1016/j.pmedr.2017.08.006 
Balcázar, H., Wise, S., Rosenthal, E. L., Ochoa, C., Rodriguez, J., Hastings, D. ... Duarte-Gardea, M. (2012). An ecological model using promotores de salud to prevent cardiovascular disease on the USMexico border: The HEART project. Preventing Chronic Disease, 9, E35. https://doi.org/10.5888/ pcd9. 110100

Bartholomew, L. K., Parcel, G. S., \& Kok, G. (1998). Intervention mapping: A process for developing theory- and evidence-based health education programs. Health Education and Behavior, 25(5), 545563. https://doi.org/10.1177/109019819802500502

Blackford, K., Jancey, J., Lee, A. H., James, A. P., Howat, P., Hills, A. P., \& Anderson, A. (2015). A randomised controlled trial of a physical activity and nutrition program targeting middle-aged adults at risk of metabolic syndrome in a disadvantaged rural community. BMC Public Health, 15(1), 284. https://doi.org/10.1186/s12889-015-1613-9

Coleman, K. J., Farrell, M. A., Rocha, D. A., Hayashi, T., Hernandez, M., Wolf, J., \& Lindsay, S. (2012). Readiness to be physically active and self-reported physical activity in low-income Latinas, California WISEWOMAN, 2006-2007. Preventing Chronic Disease, 9, E87. https://doi.org/10.5888/ pcd9.110190

Denman, C. A., Rosales, C., Cornejo, E., Bell, M. L., Munguía, D., Zepeda, T., ... Guernsey ... de Zapien, J. (2014). Evaluation of the community-based chronic disease prevention program Meta Salud in Northern Mexico, 2011-2012. Preventing Chronic Disease, 11, 140218. https://doi.org/10.5888/ pcd11.140218

Diaz, K. M., \& Shimbo, D. (2013). Physical Activity and the Prevention of Hypertension. Curr Hypertens Rep, 15(6), 659-668. https://doi.org/10.1007/s11906-013-0386-8.Physical

Guzman-Tordecilla, D. N., Llorente, B., \& Vecino-Ortiz, A. I. (2021). Evaluation of the Implementation of the Framework Convention on Tobacco Control (FCTC) in Colombia. Health Policy and Planning. https://doi.org/10.1093/HEAPOL/CZAB143

Gaffney, L. K., Lozano, O. D., Almanza, A., Ruiz, N., Mantero, A., \& Stoutenberg, M. (2019). The implementation of a national physical activity intervention in Colombia. Journal of Physical Activity and Health, 16(6), 430-436. https://doi.org/10.1123/jpah.2018-0183

Garba, R. M., \& Gadanya, M. A. (2017). The role of intervention mapping in designing disease prevention interventions: A systematic review of the literature. PLOS ONE, 12(3). https://doi.org/10.1371/ JOURNAL.PONE.0174438

Glanz, K., Rimer, B. K., \& Viswanath, K. (2008). Health Behaviour and Health Education. Health Education, 63. https://doi.org/10.1016/S0033-3506(49)81524-1

Gómez, L. F., Espinosa, G., Duperly, J., Cabrera, G. A., \& Gómez, O. L. (2002). Revisión sistemática de intervenciones comunitarias sobre actividad física en grupos específicos. Colombia Medica, 33(4), $162-170$

Heath, G. W., Parra, D. C., Sarmiento, O. L., Andersen, L. B., Owen, N., Goenka, S. ... Brownson, R. C. (2012). Evidence-based intervention in physical activity: Lessons from around the world. Lancet (London, England), 380(9838), 272-281. https://doi.org/10.1016/S0140-6736(12)60816-2

Izumi, B. T., Schulz, A. J., Mentz, G., Israel, B. A., Sand, S. L., Reyes, A. G. ... Diaz, G. (2015). Leader Behaviors, Group Cohesion, and Participation in a Walking Group Program. American Journal of Preventive Medicine, 49(1), 41-49. https://doi.org/10.1016/j.amepre.2015.01.019

Kane, L. T., Fang, T., Galetta, M. S., Goyal, D. K. C., Nicholson, K. J., Kepler, C. K. ... Schroeder, G. D. (2020). Propensity Score Matching: A Statistical Method. Clinical Spine Surgery, 33(3). https://doi. org/10.1097/BSD.0000000000000932

Kandala, N., \& Uthman, O. A. (2015). Prevalence of Hypertension in Low- and A Systematic Review and Meta-Analysis, 94(50),1-16. https://doi.org/10.1097/MD.0000000000001959

Keyserling, T. C., Samuel Hodge, C. D., Jilcott, S. B., Johnston, L. F., Garcia, B. A., Gizlice, Z., ... Ammerman, A. S. (2008). Randomized trial of a clinic-based, community-supported, lifestyle intervention to improve physical activity and diet: The North Carolina enhanced WISEWOMAN project. Preventive Medicine, 46(6), 499-510. https://doi.org/10.1016/j.ypmed.2008.02.011

Koniak-Griffin, D., Brecht, M. L., Takayanagi, S., Villegas, J., Melendrez, M., \& Balcázar, H. (2015). A community health worker-led lifestyle behavior intervention for Latina (Hispanic) women: Feasibility and outcomes of a randomized controlled trial. International Journal of Nursing Studies, 52(1), 75-87. https://doi.org/10.1016/j.ijnurstu.2014.09.005

Lawlor, D. A., Ness, A. R., Cope, A. M., Davis, A., Insall, P., \& Riddoch, C. (2003). The challenges of evaluating environmental interventions to increase population levels of physical activity: The case of the UK National Cycle Network. Journal of Epidemiology and Community Health, 57(2). https:// doi.org/10.1136/jech.57.2.96 
Leng, B., Jin, Y., Li, G., Chen, L., \& Jin, N. (2015). Socioeconomic status and hypertension: A metaanalysis. Journal of Hypertension, 33(2), 221-229. https://doi.org/10.1097/HJH.0000000000000428

Lim, S. S., Vos, T., Flaxman, A. D., Danaei, K. S., Shibuya, K. .. Memish, Z. A. (2012). A comparative risk assessment of burden of disease and injury attributable to 67 risk factors and risk factor clusters in 21 regions, 1990-2010: A systematic analysis for the Global Burden of Disease Study 2010. The Lancet, 380(9859), 2224-2260. https://doi.org/10.1016/S0140-6736(12)61766-8.A

Lucumi Cuesta, D. I. (2014). Disparities in hypertension in Colombia: A mixed-method study. ProQuest Dissertations and Theses. https:/deepblue.lib.umich.edu/bitstream/handle/2027.42/107278/ dilucumi_1.pdf. Date accessed: 24 December 2020

Lynch, E. B., Liebman, R., Ventrelle, J., Avery, E. F., \& Richardson, D. (2014). A Self-Management Intervention for African Americans With Comorbid Diabetes and Hypertension: A Pilot Randomized Controlled Trial. Preventing Chronic Disease, 11, 130349. https://doi.org/10.5888/pcd11.130349

Mcleroy, K. R., Bibeau, D., Steckler, A., \& Glanz, K. (1988). An ecological perspective on health promotion programs. Health Education Quarterly, 15(4), 351-377. https://doi. org/10.1177/109019818801500401

Mendoza-Vasconez, A. S., Linke, S., Muñoz, M., Pekmezi, D., Ainsworth, C., Cano, M. ... Larsen, B. A. (2016). Promoting Physical Activity Among Underserved Populations. Current Sports Medicine Reports, 15(4), 290. https://doi.org/10.1249/JSR.0000000000000276

Michie, S., Johnston, M., Francis, J., Hardeman, W., \& Eccles, M. (2008). From Theory to Intervention: Mapping Theoretically Derived Behavioural Determinants to Behaviour Change Techniques. Applied Psychology, 57(4), 660-680. https://doi.org/10.1111/j.1464-0597.2008.00341.x

Ministerio de Salud y Protección Social (2018). Analisis De Situación De Salud (ASIS) Colombia, 2017. Bogotá. https://www.minsalud.gov.co/sites/rid/Lists/BibliotecaDigital/RIDE/VS/ED/PSP/asisnacional-2017.pdf. Date accessed: 24 December 2020

National Administrative Department of Statistics. (2015). Metodología de Estratificación Socioeconómica Urbana Para Servicios Públicos Domiciliarios. http://www.antioquiadatos.gov.co/images/estratificacion/Manual_de_estratificacion.pdf. Date accessed: 22 November 2018

National Administrative Department of Statistics-DANE \& Banco de la República De Colombia. (2016). Chocó Quibdó informe de coyuntura económica regional. https:/www.dane.gov.co/files/icer/2015/ ICER_Choco2015.pdf. Date accessed: 22 November 2018

National High Blood Pressure Education Program. (2004). The Seventh Report of the Joint National Committee on Prevention, Detection, Evaluation, and Treatment of High Blood Pressure. The Seventh Report of the Joint National Committee on Prevention, Detection, Evaluation, and Treatment of High Blood Pressure. Retrieved from https://www.ncbi.nlm.nih.gov/books/NBK9630/

Nikoloski, Z., Alqunaibet, A. M., Alfawaz, R. A., Almudarra, S. S., Herbst, C. H., El-Saharty, S. ... Algwizani, A. (2021). Covid-19 and non-communicable diseases: Evidence from a systematic literature review. BMC Public Health, 21(1). https://doi.org/10.1186/S12889-021-11116-W

Prochaska, J. O., \& Velicer, W. F. (1997). The Transtheoretical Model of Health Behavior Change. American Journal of Health Promotion, 12(1), 38-48. https://doi.org/10.4278/0890-1171-12.1.38

Pazoki, R., Nabipour, I., Seyednezami, N., \& Imami, S. R. (2007). Effects of a community-based healthy heart program on increasing healthy women's physical activity: A randomized controlled trial guided by Community-based Participatory Research (CBPR). BMC Public Health, 7(1), 216. https://doi. org/10.1186/1471-2458-7-216

Schulz, A. J., Israel, B. A., Mentz, G. B., Bernal, C., Caver, D., DeMajo, R. ... Woods, S. (2015). Effectiveness of a Walking Group Intervention to Promote Physical Activity and Cardiovascular Health in Predominantly Non-Hispanic Black and Hispanic Urban Neighborhoods. Health Education \& Behavior, 42(3), 380-392. https://doi.org/10.1177/1090198114560015

Stacey, F. G., James, E. L., Chapman, K., Courneya, K. S., \& Lubans, D. R. (2015). A systematic review and meta-analysis of social cognitive theory-based physical activity and/or nutrition behavior change interventions for cancer survivors. Journal of Cancer Survivorship: Research and Practice, 9(2), 305-338. https://doi.org/10.1007/s11764-014-0413-z

Secretaría de Salud del Chocó (2015). Análisis de la situación en Salud del Departamento del Chocó. Quibdó. https://www.minsalud.gov.co/sites/rid/paginas/freesearchresultsdocumentos. aspx?k=choco\%20asis\&scope=Todos. Date accessed: 24 December 2020

Taylor, N. J., Sahota, P., Sargent, J., Barber, S., Loach, J., Louch, G., \& Wright, J. (2013). Using intervention mapping to develop a culturally appropriate intervention to prevent childhood obesity: The HAPPY (Healthy and Active Parenting Programme for Early Years) study. International Journal of Behavioral Nutrition and Physical Activity, 10(1), 142. https://doi.org/10.1186/1479-5868-10-142 
World Health Organization, Office for Europe (2013). Physical activity promotion in socially disadvantaged groups: principles for action. https://www.euro.who.int/_data/assets/pdf_file/0006/193092/ PHAN-brochure_ENG.pdf. Date accessed: 24 December 2020

Publisher's Note Springer Nature remains neutral with regard to jurisdictional claims in published maps and institutional affiliations.

\section{Authors and Affiliations}

\section{Deivis Nicolas Guzman-Tordecilla' ${ }^{1}$ Diego Lucumi ${ }^{1} \cdot$ Maricel Peña ${ }^{2}$}

Deivis Nicolas Guzman-Tordecilla

deivy-gt@hotmail.com

1 Alberto Lleras Camargo School of Government, Universidad de los Andes, Bogotá, Colombia

2 Programa Ampliado de Inmunizaciones, Secretaría de Salud Departamental, Chocó, Colombia 